\title{
Characterization of Gladiolus Genotypes under Khumaltar Condition of Nepal
}

\author{
Mira Dhakal ${ }^{1}$, Tul Bahadur Poon ${ }^{2}$, Pratistha Adhikari ${ }^{1}$, Suprabha Pandey ${ }^{1}$ and Shandesh Bhattarai ${ }^{3}$ \\ ${ }^{1}$ National Horticulture Research Center, NHRC, Khumaltar, Lalitpur, Nepal. @: dhakalmira13@gmail.com, \\ (iD): https://orcid.org/0000-0001-9732-5933 \\ ${ }^{2}$ Directorate of Agriculture Research, NARC, Gandaki Province, Lumle, Kaski, Nepal; \\ ${ }^{3}$ Nepal Academy of Science and Technology, Khumaltar, Lalitpur, Nepal
}

Received 20 June, 2020, Revised 10 November, 2020, Accepted 20 January, 2021, Published 30 April, 2021

Scientific Editors: UK Acharya and UK Pun

Copyright @ 2021 NARC. Permits unrestricted use, distribution and reproduction in any medium provided the original work is properly cited.

The authors declare that there is no conflict of interest.

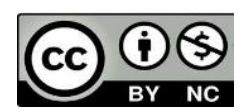

OPEN ACCESS

Licensed under the Creative Commons Attribution NonCommercial 4.0 International (CC BY-NC 4.0)

\section{ABSTRACT}

Seven promising genotypes of Gladiolus were experimented during the two consecutive years of 2014/15 and 2015/16 in the field of Horticulture Research Division, Khumaltar, Lalitpur (1332 masl) to evaluate the performances of their vegetative, floral and corm characteristics. The experiment was laid out in Randomized Complete Block Design with four replications. The treatments consisted of seven genotypes (ARSDG-01, ARSDG-02, ARSDG-03, ARSDG-04, ARSDG-05, ARSDG-06 and ARSDG-07). Fifty-four corms of each genotype were planted in the crop geometry of $25 \times 25 \mathrm{~cm}$. A total of sixteen characters were observed. The pooled results of two years data indicated significantly different except plant height, spike length, rachis length, number of cormels per mother corm and individual corm weight due to the effects of seven evaluated genotypes. Genotype ARSDG-04 was proven as the earliest one for days to the first spike emergence (73.00 days), the full spike emergence ( 76.50 days) and the first unfurling of florets (83 days). In contrast, ARSDG01 and ARSDG-06 were late genotypes for the same three characters. The number of florets/spikes was considerably high in two genotypes viz., ARSDG-06 (21.00) and ARSDG-03 (20.50). The number of daughter corms/mother corm was significantly high in ARSDG-05 (3.10) and ARSDG-04 (2.92) whereas it was minimally low in ARSDG-02 (1.66) and ARSDG-07 (1.69). Summing up all sixteen characters of evaluated genotypes, ARSDG-04 as the first, ARSDG-05 as the second and ARSDG-03 as the third have respectively emerged as superior ones as opposed by those of the rest of evaluated genotypes of Gladiolus.

Keywords: Corm and Cormels, Gladiolus, Spike and Rachis length, Unfurling

\section{सारांश}

ग्लाडिओलसका उत्कृष्ट सातवटा जातहरु समावेश गरी वि.सं. २०७२/७३ र २०७३/७४ मा बागवानी अनुसन्धान महाशाखा, खुमलटार (१३३२ मिटर समुन्द्र सतहबाट) मा अनुसन्धान गरिएको थियो। उक्त जातहरुको बानस्पतिक, फ्लोरल र कोर्मको गरी १६ वटा गुणहरुको तुलनात्मक रुपमा अनुसन्धान रेयाण्डमाइज कम्पिलट ब्लक डिजाइनमा चार पटकसम्म दोहययाइएको थियो। ती जातहरु कमशः ए आर स डि जी - ०१, ए आर स डि जी - O२, ए आर स डि जी - O३, ए आर स डि जी - O४, ए आर स डि जी - O४, ए आर स डि जी - O६ र ए आर स डि जी - O७ थिए । दुई वर्षको अनुसन्धानात्मक तथ्याङ्रबाट आएको नतिजा अनुसार ए आर स डि जी - ०४ जातमा सबैभन्दा छिटो स्पाइक निस्केको दिन (७३ दिन), पुरा स्पाइक भएको दिन (७६. ५० दिन) साथै पहिलो कोपिला लाग्ने दिन (६३ दिन) पाइयो। जबकी ए आर स डि जी - ०१ र ०६ जात चाहि ति गुणहरुमा ढिला पाइयो । बेरै संख्यामा फुल प्रति स्पाइक ए आर स डि जी - ०६ (२१.००) र ए आर स डि जी - ०३ (२०.५०) मा पाइयो ।सबैभन्दा धेरै कोर्मेलको संख्या प्रति कोर्म ए आर स डि जी - ०४ (३.१०) र ए आर स डि जी - ०४ (२.९२) मा पाइयो भने सबैभन्दा कम ए आर स डि जी - ०२ (१.७७) र ए आर स डि जी - ०७ (१.६९) मा पाइयो। अनुसन्धानात्मक नतिजा अनुसार कमशः सबै १६ वटा गुणहरु समष्टिमा मिलाएर हेर्दा सातवटा जातहरु मध्ये ए आर स डि जी - O४ सबैभन्दा उत्कुष्ट र त्यसैगरी दोस्रोमा ए आर स डि जी - O४ र तेस्रोमा ए आर स डि जी - O३ जात पर्न आयो। 


\section{INTRODUCTION}

Gladiolus (Gladiolus grandifloras L.) is one of the most popular flowers in the world which belongs to Iridaceae (Makhijani 1973). The Gladiolus consists of 250 - 260 species in the world. Among them, about 25 species are cultivated. Over 30,000 open pollinated varieties have been developed from the cultivated species (Mishra et al 2003). Gladiolus is top five cut flowers in Nepal but its production is in the decline. There are very limited Gladiolus varieties that are popular in Nepalese market and perhaps are in need of new varieties. It occupies fourth position in international cut flower trade after Rose, Chrysanthemum and Carnation (Farhat, 2004).

The Plant is very rich in its varietal diversity, but suitable varietals evaluation becomes necessary for a particular region. The varietals evaluation becomes necessity for both qualitative and quantitative characters to exploit native and exotic demand. In Gladiolus, hybridization is the most common method of improvement. Large number of exotic as well as Indian cultivars is under cultivation, and there is limited information regarding their performance of producing corms and cormels. Thus, genotypes potential for higher yield of corms and cormels need to be identified for further crop improvement.

Gladiolus is the first commercially grown cut flower crop and ranked the first position in terms of production and consumption in Nepal (Pun 2004). The area under its cultivation and growth was 18.6 hectare (FAN 2013). Large numbers of cultivars are developed every year, and hundreds of cultivars degenerated every year (Deshraj and Mishra 1998). Characterization of these cultivars and identification of suitable ones, both for cut flowers and corm/cormels production assumes significance for improving productivity and returns to the farmers.

The flowers of this plant have aesthetic, economic and social importance in our country. Taking into consideration, there is a necessity for future improvement for both quantitative and qualitative characters. Several studies of Gladiolus were undertaken by different researchers (Rao and Jamaicn1994, Negi and Raghava 1986, Negi et al 1978a), but the present study regarding the morphological variability is meagre. Hence, the present study was undertaken to compare the variability among the genotypes and to find out the suitable flower genotypes to increase the production of flower, corm and cormel and to meet the demand for the suitable regional variety. In Nepal, transformation of Gladiolus cultivation from the hobbyist activity into a commercial enterprise started only from the past three decades.

\section{MATERIALS AND METHODS}

A field study was conducted at Horticultural Research Division, Khumaltar, Lalitpur, Nepal during two consecutive years (February 2014 to August 2016) to find out elite genotype and the different seven genotype's corms were collected from Agriculture Research Station, Dailekh, Nepal. The individual plot size was $4.5 \mathrm{~m}^{2}$. Fifty-four corms of each genotype were planted in the crop geometry of $25 \mathrm{~cm}$ between the rows and within the rows of which five representative plants were selected randomly from each replication and were labelled to observe the characters.

Well decomposed farmyard manure @20 ton was applied in plots in two weeks before planting and 75 $\mathrm{kg}$ Nitrogen, $87 \mathrm{~kg}$ Phosphorus and $75 \mathrm{~kg}$ Potassium per hectare were incorporated into the soil after thorough land preparation. Remaining $75 \mathrm{~kg}$ Nitrogen was applied in two instalments i.e., at 3-5 leaf stage and at 7-9 leaf stage. Corms were planted on the $10^{\text {th }}$ of February in both years in the ridges of 1.6 $\times 1.5 \mathrm{~m}$ having furrows between the ridges. Corms were immersed in $0.2 \%$ aqueous solution of Bavistin for 20 minutes prior to planting. The uniform planting depth of 7-8 cm was maintained to plant corm. The corm size ranges from $2.75-4.75 \mathrm{~cm}$ were used. The experiment was laid out in randomized complete block design with four replications. A total of seven genotypes of Gladiolus viz., ARSDG-01, ARSDG02, ARSDG-03, ARSDG-04, ARSDG-05, ARSDG-06 and ARSDG-07 were evaluated (Figure 1). 

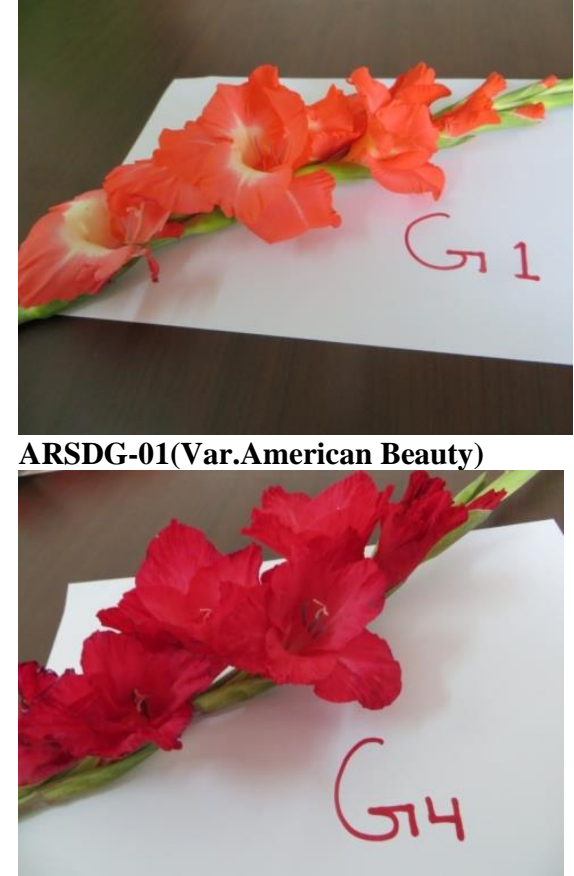

ARSDG-04(Unidentified genotype)

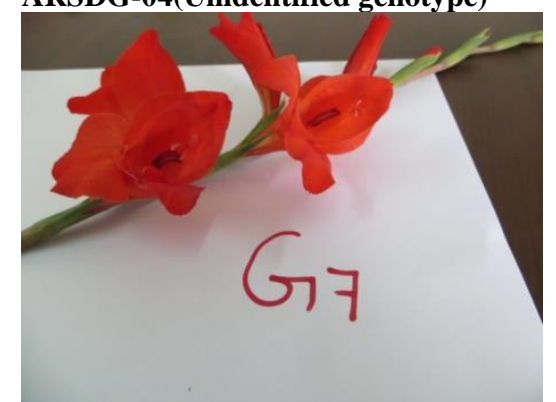

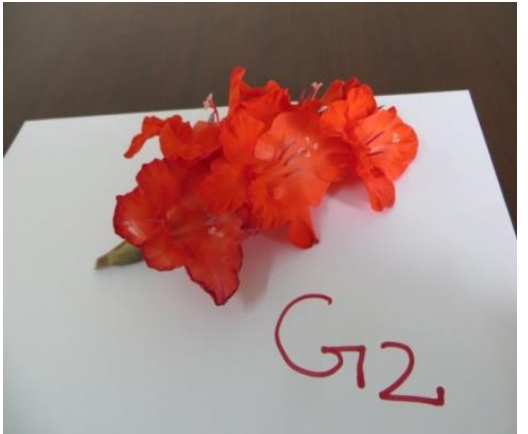

ARSDG-02(Var. Intripid)

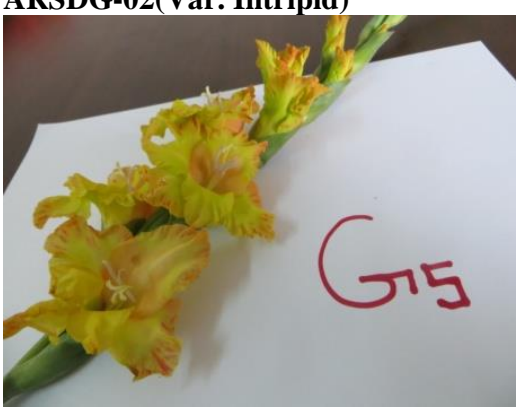

ARSDG-05(Var.Summer Sunshine)

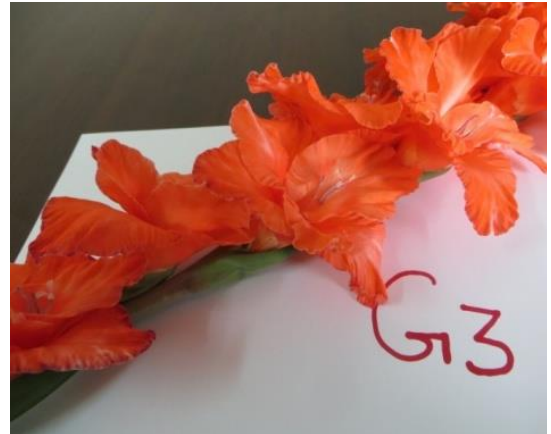

\section{ARSDG-03(Var.Ginger Red)}

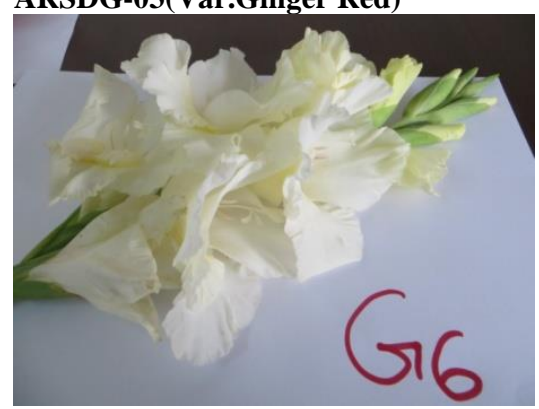

ARSDG-06(Var.White Prosperity)

\section{ARSDG-07 (Var. Pscittacinus Hybrid)}

Figure 1: Gladiolus grandifloras genotypes used in the research

Intercultural operations like weeding, irrigation, earthing-up, stacking, pesticide and fungicide applications were performed when necessary. The plant protection measures were adopted as recommended for Gladiolus. The spikes were cut when one or two lower most florets showed color but still in tight bud stage. Harvesting of corms and cormels were performed only when leaves turned into brown color (Mukhopadhyay 1995). Vegetative characters such as plant height, spike length along with rachis length were recorded at 30 and 60 DAP (Days after planting). Plant height was measured from the ground to the tip of the youngest leaf. Similarly, length of spike was measured from the internode next to fourth leaf up to the tip of the spike and recorded in centimetres and rachis length from the point of emergence of the first floret to the last floret is expresses in centimetres. Thus, data were collected and recorded from the selected parameters and the data were analysed using statistical analysis on R-software (3.0.3 version) and mean for each treatment was calculated by using DMRT.

\section{RESULTS}

The results of the experiment are presented in Table (1 to 3). Table 1 highlights the performances of five traits viz., days to the first spike emergence, days to full spike emergence, days to the first floret unfurling, days to maximum floret opening at a time and number of florets opening at a time. 
Table 1: Performances of seven genotypes of Gladiolus on the first spike emergence, full spike emergence, the first floret unfurling and maximum number of floret opening at HRD, Khumaltar during 2014/15 and 2015/16

\begin{tabular}{|l|l|l|l|l|l|}
\hline Genotypes & $\begin{array}{l}\text { Days to first } \\
\text { spike } \\
\text { emergence }\end{array}$ & $\begin{array}{l}\text { Days to full Days to first } \\
\text { spike emergence } \\
\text { floret } \\
\text { unfurling }\end{array}$ & $\begin{array}{l}\text { Days } \\
\text { maximum } \\
\text { floret opening } \\
\text { at a time }\end{array}$ & $\begin{array}{l}\text { Maximum } \\
\text { number of florets } \\
\text { opening at a time }\end{array}$ \\
\hline ARSDG-01 & $88.5 \mathrm{a}$ & $92.5 \mathrm{a}$ & $95 \mathrm{a}$ & $97 \mathrm{c}$ & $5.17 \mathrm{~b}$ \\
\hline ARSDG-02 & $87.5 \mathrm{a}$ & $91.0 \mathrm{ab}$ & $90.0 \mathrm{bc}$ & $93 \mathrm{e}$ & $5.77 \mathrm{~b}$ \\
\hline ARSDG-03 & $86.0 \mathrm{a}$ & $88 \mathrm{~b}$ & $90.5 \mathrm{abc}$ & $97 \mathrm{c}$ & $7.00 \mathrm{a}$ \\
\hline ARSDG-04 & $73.0 \mathrm{c}$ & $76.5 \mathrm{~d}$ & $83 \mathrm{~d}$ & $87.83 \mathrm{f}$ & $5.28 \mathrm{~b}$ \\
\hline ARSDG-05 & $79.0 \mathrm{~b}$ & $82 \mathrm{c}$ & $86.5 \mathrm{~cd}$ & $94 \mathrm{~d}$ & $6.00 \mathrm{~b}$ \\
\hline ARSDG-06 & $88.5 \mathrm{a}$ & $92.5 \mathrm{a}$ & $93.5 \mathrm{ab}$ & $99 \mathrm{~b}$ & $6.00 \mathrm{~b}$ \\
\hline ARSDG-07 & $85.0 \mathrm{a}$ & $87.5 \mathrm{~b}$ & $91 \mathrm{abc}$ & $105 \mathrm{a}$ & $4.23 \mathrm{c}$ \\
\hline Grand Mean & 83.92 & 87.14 & 89.92 & 96.11 & 5.63 \\
\hline CV(\%) & 3.92 & 3.63 & 4.38 & 0.16 & 13.83 \\
\hline LSD (0.05) & 3.87 & 3.72 & 4.63 & 0.18 & 0.91 \\
\hline F-test & $* * *$ & $* * *$ & $* * *$ & $* *$ & $*$ \\
\hline$* * *$ Significant at 0.001 level. In column figures with the same letter $($ s) do not differ significantly by DMRT at 0.05 level. & \\
\hline
\end{tabular}

\section{Days to the First Spike Emergence}

Highly significant variations were recorded for days to the first spike emergence (Table 1). It was considerably early in ARSDG-04 (73 days) and significantly differed from ARSDG-05 (79 days). However, the other five genotypes viz., ARSDG-01, ARSDG-06, ARSDG-02, ARSDG-03 and ARSDG07 were significantly late for days to emergence $(88.5,88.5,87.5,86$ and 85 days respectively), and the genotypes were at par with each other's.

\section{Days to the Full Spike Emergence}

Days to the full spike emergence were highly significant. It was considerably early in ARSDG-04 (76.5 days) and significantly differed from ARSDG-05 (82) in this regard, but the other five genotypes viz., ARSDG-01, ARSDG-06, and ARSDG-02 were significantly late in respect of this character $(92.5,92.5$ and 91 days respectively), and they were not at par with ARSDG-03 (88.00 days) and ARSDG-07 (87.50 days). Thus, the genotype ARSDG-05 showed early in this trait with 82 days.

\section{Days to the First Floret Unfurling}

The days to the first floret unfurling was noted to be considerably early in both ARSDG-04 (83.00 days) and ARSDG-05 (86.50 days) whereas it was significantly late in ARSDG-01 (95.00 days), ARSDG-06 (93.50 days), ARSDG-07 (91.00 days) and ARSDG-03 (90.50 days).

\section{Days to the Maximum Floret Opening at a Time}

Days to the maximum floret opening at a time was remarkably early in ARSDG-04 (88 days) and was significantly different from those of other six genotypes. It was found remarkably late in ARSDG-07 (105 days) followed significantly by ARSDG-06 (99 days) and ARSDG-03 (97 days).

\section{Maximum Number of Floret Opening at a Time}

The maximum number of floret opening at a time was considerably high in ARSDG-03 (7.00) followed significantly by ARSDG-05 (6.00) and ARSDG-06 (6.00). However, it was consequentially low in ARSDG-07 (4.23) followed by ARSDG-01 (5.17) and ARSDG-02 (5.77). 
Table 2: Performances of seven genotypes of Gladiolus on number of florets per spike, spike length, rachis length, plant height and number of marketable spies per corm at HRD, Khumaltar during 2014/15 and 2015/16

\begin{tabular}{|llllll}
\hline Genotypes & $\begin{array}{l}\text { Number of florets } \\
\text { per spike }\end{array}$ & $\begin{array}{l}\text { Spike } \\
(\mathbf{c m})\end{array}$ & $\begin{array}{l}\text { length Rachis } \\
\text { length }(\mathbf{c m})\end{array}$ & $\begin{array}{l}\text { Plant height } \\
(\mathbf{c m})\end{array}$ & $\begin{array}{l}\text { Number of } \\
\text { marketable spikes } \\
\text { per corm }\end{array}$ \\
\hline ARSDG-01 & $17.1 \mathrm{c}$ & $94.12^{\mathrm{ab}}$ & $52.10^{\mathrm{abc}}$ & $112.91 \mathrm{~b}$ & $2.99 \mathrm{a}$ \\
\hline ARSDG-02 & $17.0 \mathrm{~cd}$ & $91.94^{\mathrm{ab}}$ & $51.61^{\mathrm{abc}}$ & $112.50 \mathrm{~b}$ & $1.83 \mathrm{c}$ \\
\hline ARSDG-03 & $20.5 \mathrm{a}$ & $101.27^{\mathrm{a}}$ & $53.14^{\mathrm{ab}}$ & $118.50 \mathrm{a}$ & $1.83 \mathrm{c}$ \\
\hline ARSDG-04 & $16 \mathrm{de}$ & $100.02^{\mathrm{a}}$ & $50.50^{\mathrm{bc}}$ & $111 \mathrm{~b}$ & $2.37 \mathrm{~b}$ \\
\hline ARSDG-05 & $18.5 \mathrm{~b}$ & $100.50^{\mathrm{a}}$ & $54.50^{\mathrm{a}}$ & $114 \mathrm{ab}$ & $1.45 \mathrm{~d}$ \\
\hline ARSDG-06 & $21.0 \mathrm{~b}$ & $92^{\mathrm{ab}}$ & $49.40^{\mathrm{c}}$ & $110 \mathrm{~b}$ & $1.34 \mathrm{~d}$ \\
\hline ARSDG-07 & $15.5 \mathrm{e}$ & $88^{\mathrm{b}}$ & $49.50^{\mathrm{c}}$ & $113 \mathrm{~b}$ & $1.24 \mathrm{e}$ \\
\hline Grand Mean & 17.94 & 95.40 & 51.53 & 111.13 & 1.86 \\
\hline CV $(\%)$ & 5.17 & 5.30 & 3.35 & 2.41 & 15.89 \\
\hline LSD $(0.05)$ & 1.09 & - & - & - & 0.34 \\
\hline F-test & $* * *$ & $\mathrm{NS}$ & $\mathrm{NS}$ & $\mathrm{NS}$ & $* * *$ \\
\hline$* * *$ Significant at 0.001 level, NS: Non-significant. In column figures with the same letter $($ s) do not differ significantly by DMRT at 0.05 level.
\end{tabular}

\section{Number of Florets Per Spilke}

ARSDG-06 and ARSDG-03 produced significantly high number of florets (21.00/spike and 20.50/spike respectively) significantly followed by ARSDG-05 (18.50/spike) and ARSDG-01 (17.10 per spike). However, ARSDG-07 and ARSDG-04 produced significantly low number of spikes (15.50/spike and 16.00/spike respectively). The remaining genotypes viz., ARSDG-03 and ARSDG-06 producing average number of florets (20.50 and 21.0 per spike respectively) are at par.

\section{Spike and Rachis Length}

Both spike and rachis length showed non-significant effect due to genotypes however, spike length was observed maximum in three genotypes viz., ARSDG-03 $(101.27 \mathrm{~cm})$, followed by ARSDG-05 (100.50 $\mathrm{cm})$ and ARSDG-04 $(100.02 \mathrm{~cm})$ respectively while minimum in ARSDG-07 $(88.0 \mathrm{~cm})$.Similarly, ARSDG-05 produced the longest rachis $(54.50 \mathrm{~cm})$ followed by ARSDG-03 $(53.14 \mathrm{~cm})$ while shortest rachis length was observed in ARSDG-06(49.40 cm); however, it was at par with ARSDG-07 (49.50 $\mathrm{cm})$.

\section{Plant Height}

Though the two years combined data analysis showed non-significant to each other genotypes, ARSDG03 recorded the tallest plant $(118.50 \mathrm{~cm})$ followed by ARSDG-05 $(114.00 \mathrm{~cm})$ and ARSDG-07 $(113.00$ $\mathrm{cm})$ whereas ARSDG-06 recorded smallest plant $(110 \mathrm{~cm})($ Table 2).

\section{Marketable Spilkes per Corm}

The numbers of marketable spikes per corm were more significant among the tested genotypes (Table 2). In this study, ARSDG-01 had considerably maximum number of marketable spike (2.99 per corm), but it differed significantly from that of ARSDG-04 $(2.37 \mathrm{~cm})$. On the contrary, number of marketable spikes per corm was significantly minimum from three genotypes viz., ARSDG-7 (1.24), ARSDG-06 (1.34) and ARSDG-05 (1.45) in (Table 2). 
Table 3: Performances of seven genotypes of Gladiolus on number of daughter corm, number of cormels, corm weight, corm diameter, cormel weight and cormel diameter at HRD, Khumaltar during 2014/15 and 2015/16.

\begin{tabular}{|llllllll|}
\hline Genotypes & $\begin{array}{l}\text { No. } \\
\text { daughter } \\
\text { corm per } \\
\text { mother } \\
\text { corm }\end{array}$ & $\begin{array}{l}\text { Number } \\
\text { cormels } \\
\text { mother } \\
\text { Corm }\end{array}$ & $\begin{array}{r}\text { of } \\
\text { per }\end{array}$ & $\begin{array}{l}\text { Individual } \\
\text { corm weight } \\
\text { (gm) }\end{array}$ & $\begin{array}{l}\text { Individual } \\
\text { corm } \\
\text { diameter } \\
\text { (cm) }\end{array}$ & $\begin{array}{l}\text { Individual } \\
\text { cormel weight } \\
\text { (gm) }\end{array}$ & $\begin{array}{l}\text { Individual } \\
\text { cormel } \\
\text { diameter } \\
\text { (mm) }\end{array}$ \\
\hline ARSDG-01 & $1.86 \mathrm{~b}$ & $27.90 \mathrm{ab}$ & $46.25 \mathrm{ab}$ & $7.72 \mathrm{a}$ & $1.10 \mathrm{~b}$ & $10.87 \mathrm{~cd}$ \\
\hline ARSDG-02 & $1.66 \mathrm{~b}$ & $25.73 \mathrm{ab}$ & $46.12 \mathrm{ab}$ & $4.76 \mathrm{bc}$ & $0.80 \mathrm{~b}$ & $9.23 \mathrm{e}$ \\
\hline ARSDG-03 & $1.77 \mathrm{~b}$ & $27.41 \mathrm{ab}$ & $49.1 \mathrm{a}$ & $4.96 \mathrm{bc}$ & $2.46 \mathrm{a}$ & $9.85 \mathrm{de}$ \\
\hline ARSDG-04 & $2.92 \mathrm{a}$ & $21.38 \mathrm{~b}$ & $38.85 \mathrm{~cd}$ & $5.33 \mathrm{~b}$ & $2.29 \mathrm{a}$ & $12.32 \mathrm{bc}$ \\
\hline ARSDG-05 & $3.10 \mathrm{a}$ & $32.63 \mathrm{ab}$ & $30.78 \mathrm{e}$ & $4.6 \mathrm{bc}$ & $3.21 \mathrm{a}$ & $14.36 \mathrm{a}$ \\
\hline ARSDG-06 & $1.93 \mathrm{~b}$ & $38.35 \mathrm{a}$ & $34.0 \mathrm{de}$ & $4.04 \mathrm{c}$ & $2.93 \mathrm{a}$ & $10.64 \mathrm{de}$ \\
\hline ARSDG-07 & $1.69 \mathrm{~b}$ & $24.07 \mathrm{~b}$ & $40.77 \mathrm{bc}$ & $4.28 \mathrm{bc}$ & $2.73 \mathrm{a}$ & $13.34 \mathrm{ab}$ \\
\hline Grand Mean & 2.13 & 28.21 & 40.84 & 5.1 & 2.21 & 11.51 \\
\hline CV $(\%)$ & 12.38 & 39.63 & 13.32 & 19.83 & 40.77 & 10.86 \\
\hline LSD $(0.05)$ & 0.31 & 13.51 & 6.4 & 1.19 & 1.06 & 1.47 \\
\hline F-test & $* * *$ & $\mathrm{NS}$ & $\mathrm{NS}$ & $* * *$ & $* * *$ & $* *$ \\
\hline
\end{tabular}

NS= Non-significant, *** Significant at 0.001 level. In column figures with the same letter (s) do not differ significantly by DMRT at 0.05 level.

\section{Number of daughter corm per mother corm}

This parameter shows highly significant due to the effect of different genotypes of gladiolus (Table 3). Both genotype ARSDG-05 and ARSDG-04 recorded significantly high numbers of daughter corm i.e. 3.10 and 2.92 per mother corm, respectively (Table 3). In contrast, ARSDG-02 recorded the lowest number of daughter corm (1.66 per mother corm), nevertheless; its value was at par with those of other four genotypes viz., ARSDG-07 (1.69 per corm), ARSDG-03 (1.77 per corm), ARSDG-01 (1.86 per corm) and ARSDG-06 (1.93 per corm).

Number of cormel per mother corm

Although the number of cormels per mother varied insignificantly from 21.38 (ARSDG-04) to 38.35 (ARSDG-06) with the mean value of 28.21, the genotype ARSDG-06 was found to have produced significantly highest number of cormels per mother corm. The difference in this parameter was at par among those of the rest of six genotypes.

\section{Individual corm weight and its diameter}

Although the individual corm weight (g) was variable between 30.78 and 49.10 with the mean value of $40.87(\mathrm{~g})$, the genotype ARSDG-03 recorded significantly higher individual corm weight $(49.10 \mathrm{~g})$ as compared to those of remaining six genotypes. The difference in this parameter was at par among those of the rest of six genotypes.

The diameter of corm shows highly significant among the tested genotypes because of the influences of seven genotypes. ARSDG-01 produced considerably the widest diameter of corm $(7.72 \mathrm{~cm})$ followed significantly by ARSDG-04 $(5.33 \mathrm{~cm})$ and ARSDG-03 $(4.96 \mathrm{~cm})$. In contrast, ARSDG-06 produced the narrowest corm diameter $(4.04 \mathrm{~cm})$, however; the differences in the parameter of five genotypes viz., ARSDG-06, ARSDG-07, ARSDG-05, ARSDG-02, and ARSDG-36 were at par.

\section{Cormel weight and diameter}

Although, ARSDG-05 recorded the highest cormel weight (3.21 gm), its value did not differ statistically from those of other four genotypes viz., ARSDG-06 (2.93 gm), ARSDG-07 (2.73 gm), ARSDG-03 (2.46 gm) and ARSDG-03 (2.29 gm) (Table 3). In contrast, the rest of two genotypes viz., ARSDG-01 and ARSDG-02 recorded significantly low cormel weight $(1.10 \mathrm{gm})$ and $(0.80 \mathrm{gm}$ respectively). 
The diameter of individual cormel varied significantly from $9.23 \mathrm{~mm}$ (ARSDG-02) to $14.36 \mathrm{~mm}$ (ARSDG-05) with the mean value of $11.51 \mathrm{~mm}$ (Table 3). The individual cormel weight was statistically maximum in two genotypes viz., 'ARSDG-05' (14.36 mm) and 'ARSDG-07' (13.34 mm) while it was statistically minimum in three genotypes viz., 'ARSDG-02' $(9.23 \mathrm{~mm})$, 'ARSDG-03' $(9.65 \mathrm{~mm})$ and 'ARSDG-06' (10.64 mm).

\section{DISCUSSION}

The different genotypes showed highly significant with all the studied parameters except number of cormels per mother corm and individual corm diameter. The days to spike emergence is an important varietal character in gladiolus that might be primarily governed by the genetic makeup of the varieties. The differences in days to reach spike initiation might be due to the genetic factors of the concerned genotypes. The similar variations in different genotypes have also been reported by Kumar 2009. The number of floret opening at a time recorded in the present study was comparatively high in comparison to the findings registered by Choudhary et al (2011) under the condition of Rajasthan, India as the values of number of floret opening at a time were found varying from 3.33 (Chandani and GS-2) to 5.33 (Priscilla) with the mean value of 4.30 .

The variation in number of florets opened per spike might be attributed to the differential numbers of florets per spike and accumulation of carbohydrates due to varied leaf production in turn, variation in these aspects might be due to genetic make-up of the plants (Shakya 2006). Varietal variation in number of florets per spike was also reported by (Sindhu and Verma 1995), (Regmi 2000) and (Poon 2009). The plant height, spike length and rachis length also varied enormously among the genotypes which might be due to differences in size of corms i.e., largest corms produced tallest plant with high spike and rachis length while smallest sized corms produced the plants with the shortest height with short spike and rachis length. A similar trend in plant height grown from larger corm was reported by various researchers (Mohanty et al 1994, De and Dhiman 2003). The variation observed in plant height among the genotypes might be due to differences in genetically constituents as well as environmental effects. The number of marketable spikes per mother corm is very much important as it decided the spike yield per unit area. In gladiolus, the number of spikes/mother corm depends on the number of shoots/mother corm, which also decides the number of daughter corms/mother corm (Shiramagondi and Hanamashetti 1999). The number of marketable spikes per corm ranged from 1.24 to 2.37 , which is nearly similar to the findings of Gupta et al (2001). The variation in number of spikes per corm might be due to variability in genetic constitution of the varieties controlling the apical dominance. Similarly, the number of daughter corm and cormel per mother corm and its weight and diameter were also varied among the genotypes and they might be due to genetically constituents as well as environmental effects.

\section{CONCLUSION}

The early spike emergence, full spike emergence, days to first unfurling of florets, number of florets opening at a time were superior in ARSDG-04, ARSDG-05 and ARSDG-03. Similarly, number of daughter corms per mother corms and individual cormel weight were the highest and were directly related to floral spike quantities and propagation capacities. Meanwhile, ARSDG-03 was also proven to be having maximum number of floret opening at a time, number of florets per spike and individual corm weight. Thus, these three genotypes, ARSDG-04, ARSDG-05 and ARSDG-03 were superior to those of other four genotypes in terms of most traits under Khumaltar condition. They would be recommended for further expansion and could be utilized in varietal improvement program.

\section{ACKNOWLEDGEMENTS}

We are extremely grateful to Nepal Agricultural Research Council for providing financial support through Horticulture Research Division (HRD), Khumaltar. All the supporting staffs of NHRC are thankfully appreciated for timely providing necessary facilities, logistic supports and physical assistance for the accomplishment of this experiment. 


\section{REFERENCES}

Choudhary, M.S.K. Mood, A. Kumari and B.S, Beniwal. 2011. Evaluation of Gladiolus (Gladiolus hybrids Hort) Varieties for cut Flower production under Sub-tropical Condition of Rajasthan. Crop Research 41(1,2 and 3): 123-126.

De LC and KR Dhiman. 2003. Growth, flowering and corm production of gladiolus as influenced by grades, season and chemicals. Horticultural Journal 15(2):69-74.

Deshraj RL and HC Misra. 1998. Potential of Gladiolus cultivation in north-western Himalayan region. Annual Agriculture Research 19(4):423-428.

Farhat,T. 2004. Plant characteristics and vase life of gladiolus flowers as influenced by the preharvest and N.P.K. application and post-harvest chemical treatment. M.Sc. (Hons.). Thesis, PMAS- AAUR

Floriculture Association Nepal. 2013. Floriculture Souvenir Vol 16 Floriculture Association Nepal, Kathmandu.

Gupta P, AC Pathak and RNS Banafar. 2002. Studies on the performance of Gladiolus (Gladiolus hybridus Hort.) cultivars in Malwa region of Madhya Pradesh. South Indian Horticulture 50(4-6): 641-644.

Kumar R. 2009. Evaluation of exotic Gladiolus under sub-tropical mid-hills of Meghalaya. Indian Journal of. Agriculture Science 79(2):115-117.

Makhijani S. 1973. Arranging Gladioli. Indian Horticulture 18(3):25-28.

Mishra RL, B Singh and SK Palai. 2003. Gladiolus. In: Commercial Flowers (TK Bose, LP Yadav, P Pal, VA Parthasarthy and P Das, eds), Naya Udyog 206 Bidhan Sarani Kolkata 700006.

Mohanty CR, DK Sena and RC Das. 1994. Studies on effect of corm size and pre-planting chemical treatments of corms on growth and flowering of Gladiolus. Orissa Journal of Horticulture 22(1/2):1-4.

Mukhopadhyay A.1995. Gladiolus. Publications and Information Division, ICAR New Delhi. p. 35.

Negi SS, TVRS Sharma, SPS Raghava and PR Ramachandra.1978a. Studies on heritability and interrelationship among various characters in Gladiolus. $20^{\text {th }}$ International Horticulture Congress, Sydney, Australia Abst. 1982.

Negi SS, TVRS Sharma, SPS Raghava and VR Srinivasan. 1986. Variability studies in Gladiolus. Indian Journal of Horticulture 39:269-72.

Poon TB. 2009. Seed setting in inter varietal and interspecific crosses of Gladiolus. Ph.D Thesis. University of Agricultural Science, Banglore, India.

Pun UK. 2004. Commercial cut flower production in Nepal and status of four important cut flowers. Journal of Institute of Agriculture and Animal Science 25:17-21.

Rao TM and T Jamaicn. 1994. Quantitative and qualitative evaluation of Fusarium and tolerant hybrids of Gladiolus. In: Floriculture Technology, Trades and Trends (Prakash J and KR Bhandary, eds), Oxford and IBH Publishing Co. Pvt. Ltd. Calcutta. pp. 265-268.

Regmi HN. 2000. Performance evaluation of Gladiolus varieties with respect to growth, cut flower yield and vase life behaviour of cut-spikes in Rampur, Chitwan, Nepal. M.Sc. Thesis. Tribhuvan University, Institute of Agriculture and Animal Science.

Shakya S. 2006. Varietal evaluation and genetic characterization of Gladiolus cultivars. Master Thesis. G.B. Pant University of Agriculture and Technology Pantanagar-263145, (U.S. Nagar), Uttaranchal, India.

Sindhu SS and TS Verma. 1995. Promising varieties of Gladiolus for commercial floriculture. Haryana Journal of Horticulture Science 24(3-4): 97-203.

||-------||-------|| 